\title{
STEM-oriented high schools and dual enrolment as effective methods for promoting engineering programs
}

doi:10.2478/mape-2019-0039

Date of submission to the Editor: 04/2019

Date of acceptance by the Editor: 07/2018

MAPE 2019, volume 2, issue 1, pp. 392-398

\section{Michalene Eva Grebski*}

ORCID ID: 0000-0002-3487-4473

Northampton Community College, USA

\section{Wieslaw Grebski}

Penn State Hazleton, USA

\section{INTRODUCTION}

Historically, in the United States (USA) school systems, engineering, science and mathematics are not a high priority. Schools are focusing on the arts and humanities at the expense of mathematics and the sciences. Students are graduating from high school and getting a driver's license without knowing how an automotive engine or transmission works. All the modern conveniences and technology are there for them and everybody is using them without thinking about the science behind them. Modern technical devices on which we rely and take for granted work for many in a magical mysterious way. In the USA only $10 \%$ of high school graduates pursue engineering and engineering-related careers. This is compared to $20 \%$ in Germany and Japan. The reason for this is the lack of exposure to engineering and technical careers. Engineering programs have difficulty in recruiting qualified students despite the everincreasing demand for engineering graduates. STEM-oriented (science, technology, engineering and mathematics) high schools is a method of providing high school students with a background related to the engineering profession as well as creating excitement about the engineering design process.

\section{STEM-ORIENTED HIGH SCHOOLS}

In a STEM high school, students take all the subjects required by the high school curriculum. The STEM high school curriculum has enough room for elective subjects. Students are taking engineering and technology-related courses as elective subjects (Program of Studies). Most of these pre-Engineering courses are hands-on courses which have been developed to create excitement, spark curiosity and interest in exploring science. Those courses demonstrate how mathematics and science are being used in engineering calculations. The courses also motivate the students to take more advanced math and science courses while they are in high school. Students enrolled in a STEM high school are usually the better and higher achieving students. Poorer students usually do not choose the STEM path because they are perceived as more demanding.

\footnotetext{
*mgrebski@northampton.edu
} 
In the junior and senior years of a STEM high school, students can take a few college classes. Those college classes are being called dual enrollment. (Students are enrolled in high school and simultaneously they are enrolled in post-secondary college courses.)

The curriculum of the STEM high school in Hazleton, Pennsylvania (Hazleton Area Academy of Sciences) is shown in Table 1. The curriculum includes all the topics, English, Mathematics, Social Studies, Science, Foreign Languages, Physical Education and Fine Arts, required in secondary education by the state of Pennsylvania. The STEM concepts are being introduced in the $11^{\text {th }}$ and $12^{\text {th }}$ grades in the categories of Technology, Communication and Electives (Program of Studies).

\section{Table 1}

Curriculum of STEM high school in Hazleton, Pennsylvania USA

\begin{tabular}{|c|c|c|c|c|}
\hline Subject & Grade 9 & Grade 10 & Grade 11 & Grade 12 \\
\hline English & $\begin{array}{l}\text { English I } \\
\text { or ESL English }\end{array}$ & $\begin{array}{l}\text { English II } \\
\text { or English } \\
\text { Literature } \\
\text { and Composition } \\
\text { or ESL English II }\end{array}$ & $\begin{array}{l}\text { English III } \\
\text { or ESL English III } \\
\text { or College Board SAT } \\
\text { Preparation Course }\end{array}$ & $\begin{array}{l}\text { English IV } \\
\text { or } \\
\text { English Literature and } \\
\text { Composition } \\
\text { or } \\
\text { ESL English IV } \\
\text { or } \\
\text { Critical Reading and } \\
\text { Argumentation }\end{array}$ \\
\hline Social Studies & $\begin{array}{l}\text { American } \\
\text { Studies I }\end{array}$ & $\begin{array}{l}\text { American } \\
\text { Studies II } \\
\text { or United States } \\
\text { History }\end{array}$ & $\begin{array}{l}\text { American Studies III } \\
\text { or Science } \\
\text { Technology Society }\end{array}$ & $\begin{array}{l}\text { Economics or } \\
\text { United States Government } \\
\text { or Science Technology } \\
\text { Society }\end{array}$ \\
\hline Science & Biology IA & $\begin{array}{l}\text { Chemistry IA } \\
\text { or Chemistry IB }\end{array}$ & $\begin{array}{l}\text { Physics I } \\
\text { or Chemistry IB }\end{array}$ & Physics II \\
\hline Mathematics & $\begin{array}{l}\text { Algebra I } \\
\text { or Algebra II } \\
\text { or Plane } \\
\text { Geometry }\end{array}$ & $\begin{array}{l}\text { Algebra II } \\
\text { or Trigonometry } \\
\text { or Pre-Calculus }\end{array}$ & $\begin{array}{l}\text { Trigonometry } \\
\text { or Pre-Calculus } \\
\text { or Calculus I } \\
\text { or Calculus II }\end{array}$ & $\begin{array}{l}\text { Pre-Calculus or Calculus I } \\
\text { or } \\
\text { Calculus II or Calculus III or } \\
\text { Probability and Statistics }\end{array}$ \\
\hline $\begin{array}{l}\text { Foreign } \\
\text { Languages }\end{array}$ & $\begin{array}{l}\text { French I } \\
\text { or German I } \\
\text { or Spanish I }\end{array}$ & $\begin{array}{l}\text { French II } \\
\text { or German II } \\
\text { or Spanish II }\end{array}$ & $\begin{array}{l}\text { French III } \\
\text { or German III } \\
\text { or Spanish III }\end{array}$ & $\begin{array}{l}\text { French IV or German IV or } \\
\text { Spanish IV }\end{array}$ \\
\hline $\begin{array}{l}\text { Physical } \\
\text { Education }\end{array}$ & $\begin{array}{l}\text { Physical } \\
\text { Education }\end{array}$ & $\begin{array}{l}\text { Physical } \\
\text { Education }\end{array}$ & Physical Education & Physical Education \\
\hline Fine Arts & $\begin{array}{l}\text { Marching } \\
\text { Band I } \\
\text { or Concert } \\
\text { Choir I }\end{array}$ & $\begin{array}{l}\text { Marching Band II } \\
\text { or Concert } \\
\text { Choir II }\end{array}$ & $\begin{array}{l}\text { Marching Band III } \\
\text { or Concert Choir III }\end{array}$ & $\begin{array}{l}\text { Marching Band IV } \\
\text { or } \\
\text { Concert Choir IV }\end{array}$ \\
\hline Communication & & & $\begin{array}{l}\text { Speech } \\
\text { Communication } \\
\text { (Dual Enrollment) }\end{array}$ & $\begin{array}{l}\text { Speech Communication } \\
\text { (Dual Enrollment) } \\
\text { or } \\
\text { Professional Speaking and } \\
\text { Writing }\end{array}$ \\
\hline Technology & & & $\begin{array}{l}\text { Computer Science } \\
\text { and Programming } \\
\text { or JAVA I } \\
\text { or JAVA II } \\
\text { or Digital Web Design } \\
\text { or Management of } \\
\text { Information Systems }\end{array}$ & $\begin{array}{l}\text { Computer Science and } \\
\text { Programming } \\
\text { or JAVA I } \\
\text { or JAVA II } \\
\text { or Digital Web Design } \\
\text { or Management of } \\
\text { Information Systems }\end{array}$ \\
\hline
\end{tabular}


Table 1 (continued)

Curriculum of STEM high school in Hazleton, Pennsylvania USA

\begin{tabular}{|c|c|c|c|c|}
\hline Subject & Grade 9 & Grade 10 & Grade 11 & Grade 12 \\
\hline Electives & & & $\begin{array}{l}\text { Engineering Design } \\
\text { Process } \\
\text { (Dual Enrollment) } \\
\text { or Honors Physics II } \\
\text { or Principles of } \\
\text { Engineering } \\
\text { or Computers and } \\
\text { Robotics } \\
\text { or Computer Aided } \\
\text { Drafting } \\
\text { or Organic Chemistry } \\
\text { or Biochemistry } \\
\text { or Anatomy and } \\
\text { Physiology } \\
\text { or Genetics } \\
\text { or Astronomy }\end{array}$ & $\begin{array}{l}\text { Engineering Design } \\
\text { Process (Dual } \\
\text { Enrollment) } \\
\text { or Honors Physics II } \\
\text { or Principles of Engineering } \\
\text { or Computers and Robotics } \\
\text { or Computer Aided Drafting } \\
\text { or Organic Chemistry } \\
\text { or Biochemistry } \\
\text { or Anatomy and Physiology } \\
\text { or Genetics } \\
\text { or Astronomy }\end{array}$ \\
\hline
\end{tabular}

As shown in Table 1, in the categories of Technology, Communication and Electives, there are courses providing high school students with an introduction to engineeringrelated topics (Program of Studies). Those courses are as follows:

- Principles of Engineering,

- Computers and Robotics,

- Computer-Aided Drafting and Design,

- Introduction to Engineering Design Process,

- Computer Science and Programming,

- JAVA I,

- JAVA II,

- Digital Web Design and

- Managing Computer Information Systems.

\section{DUAL ENROLLMENT CLASSES}

Most engineering programs usually offer some introductory engineering courses which can be taken by STEM high school students. Those freshman college courses are taught by university faculty. They can be taken at a high school location during the school hours or at the college location after the school hours. STEM high school students enrolled in dual enrollment classes are required to pay a discounted college tuition based on an agreement between the university and the school district. Dual enrollment high school students are being considered college students as well. They receive a university identification card. The students can use the university library as well as the university computer system including a university email address. Their grades are also posted on a university transcript. After successfully passing the course(s), the course(s) appear on the university transcript as a college credit toward the engineering requirements. Most of those courses are transferrable between universities. If the student decides to change the university for some reason or decides to change the major/field of study, the course will be transferrable. Most students at a STEM high school take advantage of the dual enrollment opportunity. The principal of the STEM high school cooperates with local college and university engineering programs on establishing the dual enrollment opportunities. Most 
university programs are very open and supportive of the dual enrollment concept. The university programs view dual enrollment program as a part of their recruitment and retention strategies.

From the university prospective, the tuition that the student is paying for taking college courses normally offset the expenses of offering the courses. The tuition is normally discounted by $50 \%$.

Periodically there are state and federal grants available to help STEM high school students pay the college tuition. The school district in conjunction with the Engineering program offering the dual enrollment course can submit a grant proposal for funding. Some of the courses listed in Table 1. (in bold font) are being taught by college faculty as part of dual enrollment opportunities. Full-time faculty from Penn State Hazleton Engineering programs are teaching those courses at the STEM high school. Students are paying a discounted rate for taking a Penn State course. From the perspective of the Engineering program at Penn State Hazleton, this is an effective method to recruit well-prepared students into the Engineering program. Statistically $30 \%$ of the students who take the dual enrollment course offered by Penn State Hazleton enroll in the freshman year of the Engineering program after graduation from high school. Historically those students were always dedicated and hardworking. Penn State Hazleton Engineering program offers dual enrollment opportunities at four different high schools.

Dual enrollment opportunities allow the STEM high school to recruit more students by making the STEM high school more attractive to prospective students and their parents.

For many engineering programs, dual enrollment is an effective method to attract more students who have already established a good track record from the perspective of academic achievement. Dual enrollment opportunities seem to be one of the situations where all parties involved are in a winning position (Cassady, L., et al., 2019, https://www.niche.com., 2019). From the college perspective selecting the courses for dual enrollment opportunities need to be made by taking under consideration the following:

- The course needs to be a freshman-level course which does not require any prerequisites.

- The course needs to be a hands-on interactive course with a project component to create some excitement and to spark some interest in engineering and the sciences.

- The course needs to be a common course which is offered in most engineering programs, so that it would be transferrable between colleges, if the student decides to go to a different institution.

At Penn State Hazleton, the courses usually selected for dual enrollment purposes are as follows:

- Introduction to Engineering Design

This course is offered as a freshman course in most engineering programs which are ABET accredited. The course has a project component and requires six contact hours per week for fifteen weeks. The six contact hours per week include two hours of lecture and four hours of hands-on projects. Introduction to Engineering Design also contains a graphics component including computer-aided design and drafting. 
Penn State Hazleton had a very positive experience in offering this course as a dual enrollment option.

- Speech Communication

A speech communication course is normally a required course in any engineering curriculum. The course satisfies a general education requirement. A speech communication course requires three contact hours a week for fifteen weeks. The content of the course is focusing on the development of oral and written communication skills which are very important and helpful in preparing and delivering engineering presentations. Based on the experience at Penn State Hazleton, this course was considered the second choice for dual enrollment offerings (after the engineering design and graphics choice).

- Calculus I

Calculus I is a required course in any engineering curriculum. However, this course significantly increases the mathematics content in the senior year of high school. Calculus I requires four contact hours per week for fifteen weeks. The course may not encourage students to pursue an engineering career. This course is more suitable if the student is planning a math major.

- Economics

Economics either microeconomics or macroeconomics is required for most engineering programs. This course requires three contact hours per week for fifteen weeks. Economics may be a good dual enrollment option course for students who are not sure if they want to pursue an engineering or business program.

\section{Cooperation between the STEM High School in Hazleton and Local Industry}

The STEM high school in Hazleton established a working relationship with local industry under the auspices of Partners in Education. Partners in Education is an organization coordinating the need for workforce development with local vocational schools as well as post-secondary schools. Partners in Education is identifying educational needs in the area and sharing that information with secondary and postsecondary institutions. Local industry provides ongoing support to the Hazleton STEM high school as an investment in workforce development. The engineering staff from local industry often become speakers at STEM high schools and mentors to STEM high school students. Some hands-on student projects were done in cooperation with local industry (STEM, 2019).

\section{Regional Student-Research Project Fair}

As a result of the cooperation between the Penn State Hazleton Engineering program and the STEM high school, an annual regional undergraduate student research and project fair was established. This event is taking place on the last Saturday of April. This event is organized to accommodate the following participants.

- Penn State Hazleton undergraduate engineering students

- Pre-Engineering and Engineering Technology students from three local community colleges

- STEM high school students from four different school districts 
This event is held at the Penn State Hazleton Campus. There are cash awards which have been established for the best projects in the three project categories. The regional research fair has three parallel sessions in the following project categories.

- Formal PowerPoint Presentation

(This presentation describes the research project, its results and conclusions.)

- Poster Presentation

(This presentation describes the project. Most projects in this category have a prototype which has been built and is displayed near the poster.)

- Show-and Tell Projects

(Students are showing and demonstrating different hands-on projects which were completed as part of the school assignment.)

Most projects are team projects presented by a group of four to eight students. The winners of the competition in each category receive cash prizes. The first-place winner(s) also receives a $\$ 5000$ scholarship towards their college tuition if they decide to pursue their education in the Engineering program at Penn State Hazleton. This event is well-attended by students, teachers, parents and the families. Lunch and refreshments are being provided by Penn State Hazleton. The judges for the event are Penn State Hazleton faculty, senior-level Engineering students and engineers from local industry.

\section{CONCLUSIONS}

The STEM high school in the Hazleton Area School District established approximately eight years ago has proven to be an effective method in promoting careers in science, technology, engineering and mathematics. Those careers are in great demand in the knowledge-based economy. The STEM high school in Hazleton is providing high quality students to the engineering programs at Penn State and other institutions of higher education in the area. Statistically in 2015, there was a significant increase in the number of high school students pursuing science and engineering careers in the USA (The Framework, 2014, Sanders, M., 2009, Strauss, M., 2017).

Part of the reason for this increase was the demand for engineering professions. STEM high schools significantly contributed to the preparation of high school students enrolling in engineering programs. Dual enrollment opportunities available to high school students allow the better students to participate in college courses and to gain college experience while in high school.

\section{REFEENCES}

Cassady, L., Keating, K., and Young, V. (2019). Dual Enrollment Lessons Learned on SchoolLevel Implementation. [online] Virginia: EDJ Associates. Available at: https://www.2.ed.gov/programs/skp/finaldual.pdf/ [Accessed 01 Jul. 2019].

https://www.niche.com/K12/search/best-schools-for-stem/s/pennsylvania/ [Accessed 01 Jul. 2019].

Pennsylvania Out-of-School-Time. In: STEM. Project Accelerate. Available at: https://www.pa.stem.ost.info/ [Accessed 01 Jul. 2019].

Program of Studies, (2018). STEM School: Hazleton Area Academy of Sciences - School Year 2017-2018 at: https://www.hasdK12.org/Domain.1118 [Accessed 01 Jul. 2019].

Sanders, M. (2009). STEM Education, STEMmania. The Technology Teacher. International Technology Education Association at: https://vtechworks.lib.vt.edu/ [Accessed 01 Sep. 2019]. 
Strauss, M. (2017). About a Third of Americans Would Tell High Schoolers Seeking Career Advice to Enter a STEM-related Field. Pew Research Center at: https://www.pewsearch.org/fact-tank/2017/09/26/ [Accessed 01 Sep. 2019].

The Framework for Integrative Science, Technology, Engineering and Mathematics (2014). In: STEM. Education Endorsement Guidelines. Pennsylvania Department of Education at: https://www.education.pa.gov/Documents/ [Accessed 01 Sep. 2019].

Abstract. The paper describes the different methods of promoting science, technology, engineering and mathematics to meet the demand for a qualified workforce in those areas. STEM-oriented (Science Technology Engineering Mathematics) high schools combined with dual enrollment opportunities have been proven to be effective methods of promoting engineering careers. The article also discusses the typical curriculum of STEM high schools as well as the selection of college courses for the dual enrollment option.

Keywords: dual enrollment, STEM schools, engineering careers, technical preparation, promoting science 